\title{
AVIAN PATHOGENIC ESCHERICHIA COLI: DIAGNOSIS, VIRULENCE AND PREVENTION
}

\author{
Maja Velhner ${ }^{*}$, Ljiljana Suvajdžić ${ }^{2}$, Dalibor Todorović ${ }^{1}$, \\ Dubravka Milanov ${ }^{1}$, Gordana Kozoderović ${ }^{3}$ \\ ${ }^{1}$ Scientific Veterinary Institute "Novi Sad", Novi Sad, Serbia \\ ${ }^{2}$ University of Novi Sad, Faculty of Medicine, \\ Department of Pharmacy, Novi Sad, Serbia \\ ${ }^{3}$ University of Novi Sad, Faculty of Education in Sombor, Department \\ of Natural Sciences and Management in Education, Serbia
}

\section{Abstract}

Avian pathogenic Escherichia coli (APEC) causes colibacillosis within poultry flocks all around the world. There is a number of virulence mechanisms involved in the disease process in poultry and determination of some of the responsible genes is important for diagnosis of colibacillosis. In this work, research data regarding diagnostics of APEC and how certain clonal lineages could cause infection in different hosts is presented. In order to determine virulence genotype of APEC, multiplex polymerase chain reaction, based on a published sequence of seven pairs of primers (iroN, ompT, hly F, iss, iutA, elitC and $c v a C$ ), was used in our laboratory. It was established in the research of other scientists that isolates with two or more of these genes can develop pathogenic phenotype, while isolates with one or none of the genes are mostly commensal E. coli. Additionally, virulence mechanisms in APEC were also briefly described. It was emphasized that resistance genes and virulence genes are sometimes co-located on the same plasmid and that such plasmids could be shared among related or unrelated bacteria species. Since APEC often confers resistance to antibiotics, the therapy is less effective in poultry with multidrug resistant strains. It was concluded that good management practice, treatment with probiotics and/or vaccination are necessary to reduce colibacillosis outbreaks. This approach is even more pronounced since APEC resides in intestine of healthy poultry and could cause disease if poultry is exposed to various stressors.

Keywords: Escherichia coli, antibiotic resistance, virulence mechanisms, diagnostic, prevention

\footnotetext{
${ }^{1}$ Corresponding author: maja@niv.ns.ac.rs
} 


\title{
AVIJARNA PATOGENA ESCHERICHIA COLI: DIJAGNOZA, VIRULENCIJA I PREVENCIJA
}

\author{
Maja Velhner ${ }^{1^{*}}$, Ljiljana Suvajdžić ${ }^{2}$, Dalibor Todorović ${ }^{1}$ \\ Dubravka Milanov $^{1}$, Gordana Kozoderović ${ }^{3}$ \\ ${ }^{1}$ Naučni institut za veterinarstvo „Novi Sad“, Novi Sad, Srbija \\ ${ }^{2}$ Univerzitet u Novom Sadu, Medicinski fakultet, Departman za farmaciju, Novi Sad \\ ${ }^{3}$ Univerzitet u Novom Sadu, Fakultet za obrazovanje Sombor, \\ Departman za prirodne nauke, menadžment i obrazovanje
}

\section{Kratak sadržaj}

Avijarna patogena Escherichia coli (APEC) je uzročnik kolibaciloze u jatima živine širom sveta. Brojni mehanizmi virulencije uzročnika su uključeni u patogenezu oboljenja, zbog čega je determinacija gena virulencije važna u dijagnostici kolibaciloze. $\mathrm{U}$ ovom radu prezentujemo rezultate istraživanja koji se odnose na dijagnostiku APEC-a i pojavu infekcija izazvanih određenim klonovima kod različitih domaćina. Za određivanje virulentnog genotipa izolata APEC-a, primenili smo prethodno opisanu metodu multipleks PCR sa sedam parova prajmera (iroN, ompT, $h l y F$, iss, iutA, elitC and $(v a C)$. Rezultati ranijih istraživanja pokazuju da izolati APEC koji imaju dva ili više gena virulencije mogu da razviju patogeni fenotip, dok su izolati bez ili sa jednim genom, uobičajeno komensali. Kod izolata APEC-a često se ustanovljava rezistencija na antibiotike, zbog čega je terapija manje uspešna u tretmanu infekcija izazvanih sojevima sa multiplom rezistencijom. Uz prikaz mehanizama virulencije APEC-a, u radu iznosimo i literaturne podatke koji ukazuju da su geni za virulenciju i rezistenciju na antibiotike ponekad locirani na istim plazmidima koji lako mogu da se prenesu na druge srodne i nesrodne vrste bakterija. Zbog činjenice da se APEC može naći u intestinalnom traktu i zdravih životinja, u zaključku istraživanja ukazujemo na značaj primene prakse dobrog menadžmenta, upotrebe probiotika $\mathrm{i} / \mathrm{ili}$ vakcinacije $\mathrm{u}$ cilju smanjenja pojava kolibaciloza na farmama živine.

Ključne reči: Escherichia coli, rezistencija na antibiotike, mehanizmi virulencije, dijagnostika i prevencija 


\section{INTRODUCTION}

Avian pathogenic Escherichia coli (APEC) causes outbreaks of colibacillosis in poultry all around the world. The disease is often provoked if poultry is exposed to various stressors. Infections with viruses causing acute disease and immunosuppression (such as Infectious bursal disease virus) or those which affect the respiratory tract of chickens (such as Infectious bronchitis virus) are often followed by the "episodes" of colisepsis. Sometimes APEC induces higher mortality rate in poultry flocks than the viruses themselves. However, many other non-infectious factors may influence disease symptoms caused by APEC. Those non-infectious factors are often overcrowding, ammonia, heat during summer months, poor sanitation etc. (Barnes et al., 2008). Besides mortality, APEC can also cause decreased body weight in chickens and condemnation of carcasses at the processing plants, which lead to economic losses for the farmers. It is also important to note that many APEC isolates are multidrug resistant, which reduces the effectiveness of antibiotic treatment. As APEC is an invasive bacterial pathogen, it is not possible to completely eliminate the clinical symptoms in poultry flocks, even if farmers substantially improve management to decrease the risks of colibacillosis.

\section{DIAGNOSIS}

The basic diagnostic criterion for identification of $E$. coli is its characteristic growth on McConkey agar (bright pink colonies surrounded by precipitate). The colonies may also appear as mucoid, large and sticky. Brief biochemical characterization include indol (+), methyl red (+), Voges Proskauer (-) and citrate (-). Automatic systems are also utilized for the identification of $E$. coli, mostly by VITEK and MALDI TOFF mass spectrometry. The polymerase chain reaction (PCR) is also suitable for the detection of the specific genes such as $\mathrm{gadA} / B$ genes that encode enzyme glutamate decarboxylase in E. coli (McDaniels et al., 1996). In the case of coli sepsis, E. coli is isolated from parenchymatous organs of the chicken and/or from the bone marrow. However, there are more localized pathological changes, such as coliform omphalitis, coliform-cellulitis, swollen head syndrome, coliform orchitis, veneral colibacillosis, coliform salpingitis, diarrheal disease, which require specific diagnostic methods. Colisepticemia develops when APEC enters the bloodstream, often when the infection of the respiratory tract is already established. It is important in diagnostics to take into account that other bacteria, such as pasteurella, salmonella, streptococci and chlamidiophila, also cause acute septice- 
mic disease and their identification must be included in differential diagnosis (Barnes et al., 2008).

In the research work of Johnson et al., (2006) and Johnson et al., (2008a) it was shown that iroN, ompT, $h l y F$, iss, iutA, virulence genes are found in more than $70 \%$ of APEC isolates. These genes are located on a large virulence plasmid, called ColV plasmid (Johnson et al., 2008a). E. coli isolates with two or more of the aforementioned virulence genes could develop pathogenic phenotype for day old chickens, while isolates with one or none of the virulence genes (iroN, ompT, hlyF, iss, iutA) are usually commensal strains (Johnson et al 2008a, De Oliveira et al., 2015). Therefore, molecular detection of virulence genes in presumptive APEC isolates is useful in order to improve diagnostic protocol.

\section{PHYLOGENY AND VIRULENCE OF Escherichia coli}

Phylogenetic characterization of E. coli is an important molecular typing method. Based on PCR detection of two genes and a DNA fragment (with primers chuA1/2, yjaA.1/2 and TspE4C2.1/2.2), E. coli is assigned to four main phylogenetic groups: A, B1, D, B2 (Clermont et al., 2000), as it is shown in Figure 1. This scheme is used especially for PCR typing of extraintestinal E. coli isolates which cause infections of the urinary tract (UTI) in humans and animals. Regardless of the origin of the isolates (human or animal), these extraintestinal pathogenic E. coli (ExPEC) belong mainly to phylogenetic group B2.

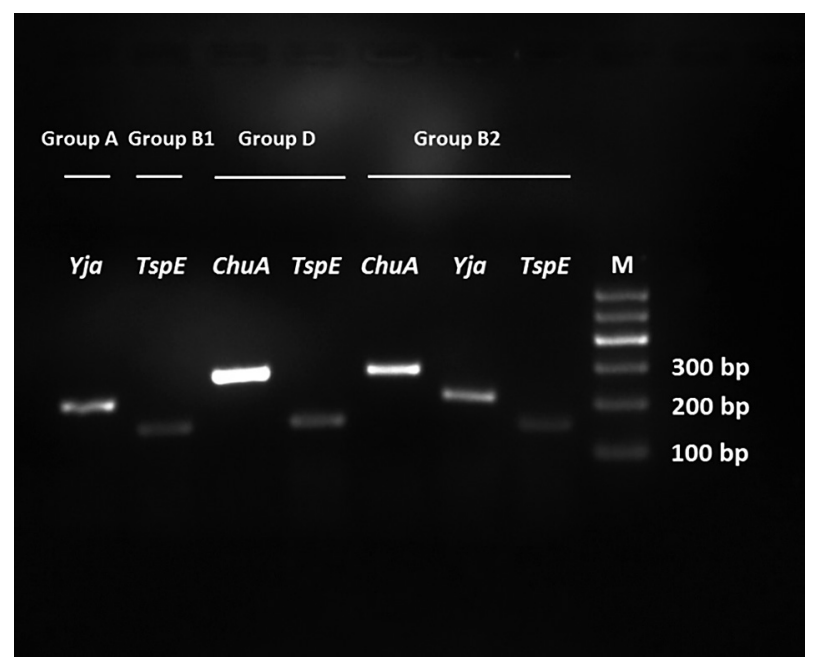

Figure 1. Phylogenetic characterization of E. coli isolates by PCR, with three set of primers (Figure prepared by Dalibor Todorović, Scientific Veterinary Institute "Novi Sad") 
Such close relationship among the ExPEC isolates is associated to their virulence plasmids. In the research work of Johnson et al., (2008a) and Johnson et al., (2009), APEC isolates from poultry lesion due to colibacillosis belong to phylogenetic groups A, B1, D and to group B2. Moreover, the link between phylogenetic type, multi-locus sequence type and virulence type was found between human ExPEC and APEC isolates in the research work of MoulinSchouleur et al., (2007). It was documented that ExPEC and APEC of serotypes $\mathrm{O} 18: \mathrm{K} 1, \mathrm{O} 2: \mathrm{K} 1$ and $\mathrm{O} 1: \mathrm{K} 1$, that belong to subcluster $\mathrm{B} 2-1$, are highly pathogenic for day old chickens and, in addition, human ExPEC-B2-1 isolates have caused avian colibacillosis in 3.5 week old birds which was similar to diseases caused by APEC. High genetic similarity between those isolates and their pathogenicity indicate that there is no strict host specificity for some of the ExPEC and APEC isolates. APEC isolates belonging to serotype O78 belong to phylogenetic group B1 and D and, according to their MLST type and common virulence patterns, they present a different phylogenetic cluster comparing to group B2-1 (Moulin-Schouleur et al., 2007). It is worth mentioning that some of the E. coli isolates from retail products were found to contain virulence genes from PAI (Pathogenicity islands). In the same research, the gizzard content was assumed to be the source of contamination and significant number of E. coli isolates from retail belonged to phylogenetic group B1 (Johnson et al., 2009).

In theory, APEC poses a threat to human health, but the concrete experimental evidence for this assumption is still lacking. Therefore, to evaluate the ability of $E$. coli of animal origin to cause disease in humans, animal infection models are utilized by inducing sepsis in mouse and meningitis in neonatal rats. Such animal experiments are used to study the ability of APEC to establish infection in different hosts (Johnson et al., 2012). In an example in the research of Skyberg et al., (2006) it was shown that commensal E. coli, which had conjugative virulence plasmid, significantly increased the ability of E. coli to kill chicken embryo, its ability to grow in human urine and colonize the murine kidney. The host specificity of pathogenic $E$. coli is also determined by a set of specific adhesins or other surface associated or secreted molecules which promote bacteria colonization and dissemination (Clermont et al., 2011, Pan et al., 2014). Important mechanisms of the host specificity are also the immune evasion and nutrient acquisition systems in bacteria (Pan et al., 2014).

In our research, we used a multiplex PCR method for detection of virulence genes that are often found on conjugative virulence plasmids in APEC strains (Rodriguez-Siek et al., 2005, Johnson et al., 2008a) (Figure 2). The following primes were included in the master mix: iroN, ompT, hlyF, iss, iutA, 
elitC and $c v a C$. The iroN gene encodes outer membrane siderophore receptor IroN which is participating in the transport of ferric siderophores in Gram negative bacteria (siderophores are complex molecules that enable bacteria to uptake the iron in iron poor environments, such as urine). Iron is important for metabolic functions of bacteria and for their survival in the host (Hantke et al., 2003). The ompT gene encodes outer membrane protease (OmpT) which catalyzes the activation of plasminogen to plasmin, inactivates antibiotic peptides and colicin. In addition, it has an important function in degradation and proteolysis of proteins (McCarter et al., 2004). The $h l y F$ gene is frequently found in APEC isolates and on ColV plasmids. The HlyF (putative avian hemolysin) is directly involved in the production of outer membrane vesicles (OMVs). These vesicles are transporting virulence factors of bacteria promoting pathology process in the infected host (Murase et al., 2016). Similar to $h l y F$, increased serum survival gene (iss) is also found in ColV plasmid, but it could also be found in a bacterial chromosome. The function of Iss protein is to protect bacteria from the killing effect of the complement (Johnson et al., 2006, Johnson et al., 2008b). The outer membrane receptor gene for ferric aerobactin is iutA and that gene is also very frequently detected in APEC isolates compared to commensal E. coli (Johnson et al., 2006, Johnson et al., 2008a). All of these genes are often located on pathogenicity island-PAI on host chromosome or plasmids. In addition, several plasmid borne genes ( $c v a A, c v a B, c v a C$ and $c v i$ ) participate in the synthesis, export and immunity of a peptide antibiotic Colicin V. These molecules are involved in killing competitor sensitive bacteria in order to uptake essential nutrients and they have been discovered in Enterobacteriaceae (Gérard et al., 2005). 


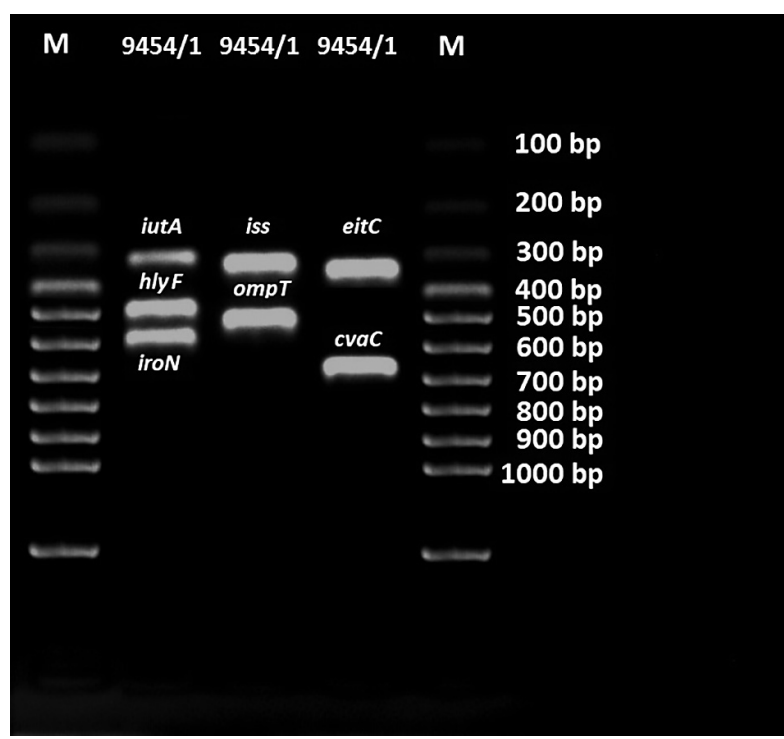

iutA-302 bp hlyF-450 bp iroN-553 bp iss $-323 \mathrm{bp}$ ompT-496 bp eitC-980 bp cvaC-678 bp

Figure 2: Virulence gene detection in E. coli isolate (APEC strain 9454/1) (Figure prepared by Dalibor Todorović, Scientific Veterinary Institute "Novi Sad")

\section{COEXISTENCE OF VIRULENCE GENES AND GENES ENCODING RESISTANCE TO ANTIBIOTICS}

E. coli are versatile bacteria which have the ability to survive in various hostile environments. There are a number of genetic mechanisms $E$. coli uses to survive in nature and different hosts. Most important are the mechanisms of virulence and resistance to antibiotics, heavy metals, disinfectants, detergents and many other toxic substances. E. coli share their genetic material within closely related or even unrelated population of bacteria via horizontal gene transfer. For example, Salmonella Kentucky isolates from poultry flocks in the USA have been found to contain virulence plasmid ColV from APEC. Therefore, $S$. Kentucky manage to persist on poultry farms even in the presence of other highly competitive Salmonella strains, mainly because they acquire virulence plasmids (Johnson et al., 2010a). Healthy poultry may also harbor extraintestinal pathogenic $E$. coli in their intestinal tract. In fact, it was shown that number of fecal isolates from poultry possess virulence genes and can cause disease in animal models of infection (Stromberg et al., 2017). Therefore, it is difficult to prevent infection of chickens with APEC, and management and prophylaxis are still the only ways to cope with colibacillosis worldwide. 
The growing problem is resistance to antibiotics, especially to fluoroquinolones and beta lactam antibiotics in E. coli strains ( $\mathrm{Su}$ et al., 2016). The research work conducted in Serbia has shown high resistance to fluoroquinolones in E. coli isolates from clinical bovine mastitis, pigs and wildlife (Todorović et al., 2018; Velhner et al., 2018). One isolate from a pig had multiple mutations on topoisomerase genes, conferring resistance to ciprofloxacin and also carried bla $a_{\text {CTX-M-1 }}$ gene (Todorović et al., 2018). However, in poultry industry in Serbia third generation cephalosporins are not frequently used, or not at all, but $E$. coli can gain resistance to these antibiotics by conjugative transfer of multidrug resistant plasmids. The important trait is when bacteria possess antibiotic resistance genes and virulence genes. For instance, genetic analysis of the ColBM plasmid from E. coli isolate (ExPEC 408) that have caused peritonitis in commercial laying hen was sequenced and studied in detail. It was documented that ColBM is a complex plasmid with resistance genes and virulence associated genes and that $E$. coli with ColBM plasmid caused colibacillosis in day old chickens and induced bacteremia and meningitis in rat model of infection (Johnson et al., 2010b). It is also important to note that virulence genes were found on a $b l a_{\mathrm{CMY}-2}$ conjugative plasmid (IncF) from the APEC strain that caused colibacillosis in broiler chicken (Touzain et al., 2018). Therefore, bacteria with plasmids conferring virulence and resistance to antibiotics may have increased fitness and consequently their ability to survive in host and environment will increase as well (Schroeder et al., 2017).

\section{PREVENTION}

Proper management practice and vaccination are important to prevent colibacillosis. However, there are a number of serotypes and virulence types of $E$. coli and it is difficult to develop universal vaccines against APEC. It is yet to be learned what the benefits of free range breeding system would be to the poultry industry. More knowledge about E. coli pathogenesis is necessary in order to design more efficient vaccines or drugs. Meanwhile, the best way to prevent viral and bacterial diseases in poultry industry and to decrease outbreaks caused by infectious agents, is to implement strict farm biosecurity measures and animal welfare systems.

In conclusion, it is important to identify virulence genes in E.coli isolates from poultry and to recommend effective management, probiotic treatment and/or vaccination if needed. Such approach will contribute to the reduction of outbreaks caused by APEC and will decrease the dissemination of virulent and multidrug resistant bacteria in the entire food chain. 


\section{ACKNOWLEDGMENT}

This work was financially supported by a grant from the Ministry of Education, Science and Technological Development, Republic of Serbia, Project number TR 31071.

\section{REFERENCES}

1. Barnes H.J., Nolan L.K., Vaillancourt J.P.: Colibacillosis, in: Diseases of Poultry (12 ${ }^{\text {th }}$ edition), Editor in chief , Saif YM, Blackwell Publishing Ltd, Ames, Iowa, USA, 691-793, 2008.

2. Clermont O., Bonacorsi S. and Bingen E.: Rapid and simple determination of the Escherichia coli phylogenetic group. Applied and Environmental Microbiology, 66, 4555-4558, 2000.

3. Clermont O., Olier M., Hoede C., Diancourt L., Brisse S., Keroudean M., Glodt J., Picard B., Oswald E., Denamur E.: Animal and human pathogenic Escherichia coli strains share common genetic backgrounds. Infection, Genetics and Evolution, 11, 3, 654-662, 2011.

4. De Oliveira A.L., Rocha D.A., Finkler F., de Moraes L.B., Barbieri N.L., Pavanelo D.B., Winkler C., Grassotti T.T., de Brito K.C.T., de Brito B.G., Horn F.: Prevalence of ColV plasmid-linked genes and in vivo pathogenicity of avian strains of Escherichia coli. Foodborne Pathogens and Disease, 12, 679-685, 2015.

5. Gérard F., Pradel N., Wu L.F.: Bactericidal activity of Colicin V is mediated by an inner membrane protein, $\mathrm{SdaC}$, of the Escherichia coli. Journal of Bacteriology, 187, 1945-1950, 2005.

6. Hantke K., Nicholson G., Rabsch W., Winkelmann G.: Salmochelins, siderophores of Salmonella enterica and uropathogenic Escherichia coli strains, are recognized by the outer membrane receptor IroN. Proceedings of National Academy of Sciences USA (PNAS), 100, 3677-3682, 2003.

7. Johnson T.J., Siek K.E., Johnson S.J., Nolan L.K.: DNA sequence of a ColV plasmid and prevalence of selected plasmid-encoded virulence genes among avian Escherichia coli strains. Journal of Bacteriology, 188, 745-758, 2006.

8. Johnson T.J., Wannemuehler Y., Doetkott C., Johnson S.J., Rosenberger S.C., Nolan L.K.: Identification of minimal predictors of avian pathogenic Escherichia coli virulence for use as a rapid diagnostic tool. Journal of Clinical Microbiology, 46, 3987-3996, 2008a.

9. Johnson T.J., Wannemuehler Y.M., Nolan L.K.: Evolution of the iss gene in Escherichia coli. Applied and Environmental Microbiology, 74, 2360-2369, $2008 \mathrm{~b}$. 
10. Johnson T.J., Logue C.M., Wannemuehler Y., Kariyawasam S., Doetkott C., DebRoy C., White D., Nolan L.K.: Examination of the source and extended virulence genotypes of Escherichia coli contaminating retail poultry meat. Foodborne Pathogens and Diseases, 6, 657-667, 2009.

11. Johnson T.J., Thorsness J.L., Anderson C.P., Lynne A.M., Foley S.L., Han J., Fricke W.F., McDermott P.F., White D.G., Khatri M., Stell A.L., Flores C., Singer R.S.: Horizontal gene transfer of a ColV plasmid has resulted in a dominant avian clonal type of Salmonella enterica serovar Kentucky. PLoS ONE, 5, 12, e15524, 2010a.

12. Johnson T.J., Jordan D., Kariyawasam S., Stell A.L., Bell N.P., Wannemuehler Y.M., Alarcón F.C., Li G., Tivendale K.A., Logue C.M., Nolan L.K.: Sequence analysis and characterization of a transferable plasmid encoding multidrug resistance and enabling zoonotic potential for extraintestinal Escherichia coli. Infection and Immunity, 78, 1931-1942, 2010b.

13. Johnson T.J., Wannemuehle Y., Kariyawasam S., Johnson J.R., Logue C.M., Nolan L.K.: Prevalence of avian-pathogenic Escherichia coli strain O1 genomic islands among extraintestinal and commensal E. coli isolates. Journal of Bacteriology, 194, 2846-2853, 2012.

14. McCarter J.D., Stephens D., Shoemaker K., Rosenberg S., Kirsch J.F., Georgiou G.: Substrate specificity of the Esherichia coli outer membrane protease OmpT. Journal of Bacteriology, 186, 5919-5925, 2004.

15. McDaniels A.E., Rice E.W., Reyes A.L., Johnson C.H., Haugland R.A., and Stelma G.N.: Confirmational identification of Escherichia coli, a comparison of genotypic and phenotypic assays for glutamate decarboxylase and $\beta$-D-glucuronidase. Applied and Environmental Microbiology, 62, 33503354, 1996.

16. Moulin-Schouleur M., Répérant M., Laurent S., Brée A., Mignon-Grasteau S., Germon P., Rasschaert D., Schouler C.: Extraintestinal pathogenic Escherichia coli strains of avian and human origin: Link between phylogenetic relationship and common virulence patterns. Journal of Clinical Microbiology, 45, 3366-3376, 2007.

17. Murase K., Martin P., Porcheron G., Houle S., Helloin E., Pénary M., Nougayréde J.P., Dozois C.M., Hayashi T., Oswald E.: HlyF produced by extraintestinal pathogenic Escherichia coli is a virulence factor that regulates outer membrane vesicle biogenesis. The Journal of Infectous Diseases, 213, 856-865, 2016.

18. Pan X., YangY., Zhang J.R.: Molecular basis of host specificity in human pathogenic bacteria. Emerging Microbes and Infections, 3,3,e23, 2014.

19. Rodriguez-Siek K.E., Giddings C.W., Doetkott C., Johnson T.J., Nolan L.: 
Characterizing the APEC pathotype. Veterinary Research, 36, 241-256, 2005.

20. Schroeder M., Brooks B.D., Brooks A.E.: The complex relationship between virulence and antibiotic resistance. Genes, 8, 39, 2017.

21. Skyberg J.A., Johnson T.J., Johnson J.R., Clabots C., Logue C.M., Nolan L.K.: Acquisition of avian pathogenic Escherichia coli plasmid by a commensal E. coli isolate enhances its ability to kill chicken embryos, grow in human urine and colonize the murine kidney. Infection and Immunity, 74, 6287-6292, 2006.

22. Stromberg Z.R., Johnson J.R., Fairbrother J.M., Kilbourne J., Van Goor A., Curtis 3rd R., Mellata M.: Evaluation of Escherichia coli isolates from healthy chickens to determine their potential risk to poultry and human health. PLoS ONE, 12, 76, e0180599, 2017.

23. Su Y., Yu C.Y., Tsai Y., Wang S.H., Lee C., Chu C.: Fluoroquinolone-resistant and extended-spectrum $\beta$-lactamase-producing Escherichia coli from the milk of cows with clinical mastitis in Southern Taiwan. Journal of Microbiology, Immunology and Infection, 49, 892-901, 2016.

24. Todorović D., Velhner M., Grego E., Vidanović D., Milanov D., Krnjaić D., Kehrenberg C.: Molecular characterization of mltidrug-resistant Escherichia coli isolates from bovine mastitis and pigs in the Vojvodina Province, Serbia. Microbial Drug Resistance 24, 95-103, 2018.

25. Touzain F., Le Devendec L., de Boisséson C., Baron S., Jouy E., Pein-Guyomard, Blanchard Y., Kempf I.: Characterization of plasmids harboring $b l a_{\mathrm{CTX}-\mathrm{M}}$ and $b l a_{\mathrm{CMY}}$ genes in E. coli from French broilers. PLoS ONE, 13, 1, e0188768, 2018

26. Velhner M., Todorović D., Grego E., Jovičić B., Punić B., Stojanov I., Kehrenberg C.: Fluoroquinolone-resistant and extended-spectrum betalactamase producing Escherichia coli isolates fom free-living wild animals. Veterinary Microbiology, 223, 168-172, 2018.

Primljeno: 24.10.2018.

Odobreno: 18.11.2018. 